\section{The Proposed Employment Relations Act}

\section{Alan Geare*}

The Labour Party claims the current Employment Contracts Act is not compatible with the economic environment Labour wants to foster. If elected, Labour will introduce in its place the Employment Relations Act. This paper analyses the proposed reforms and concludes the reforms are, in the main, superficial and will have little impact on New Zealand industrial relations.

\section{Introduction}

This paper briefly outlines the changes in industrial legislation up to the Employment Contracts Act 1991 (EC Act). The lead paper in this issue by the shadow Deputy Prime Minister Helen Clark, outlines the proposed amendments that the Labour Party will make to the EC Act should it win the 1993 General Election. These proposed amendments will be embodied in a new Act - the Employment Relations Act. This paper examines Labour's proposed changes and concludes that the changes are without real substance or significance. Certainly the limited extent of the amendments make the title of the Act not only unnecessary, but ironically the most noticeable change.

\section{Background}

Although it was re-enacted six times and amended numerous times, the Industrial Conciliation and Arbitration Act 1894 (ICA Act) basically determined the legal framework for private sector New Zealand industrial relations for ninety years. Admittedly in 1973 the title of the principal Act was changed (setting a trend which has been followed ever since) but the apparently "new" Industrial Relations Act 1973 was "little more than the old pattern revamped" (Woods, 1974: 3) and like the various different ICA Acts over the years "left untouched the basic precepts on which the 1894 Act was founded" (Yearbook, 1973: 894).

The original ideology behind the ICA Acts was basically paternalistic. There was a desire to foster unions as unions were seen as the best protection for workers. While collective bargaining was seen as desirable if peaceful solutions could be reached, the state provided conciliators to chair the bargaining sessions. Strikes and lockouts were illegal and, if negotiation failed, arbitration was provided to achieve a settlement. Over the years, the ideology became more "unitarist" to use the terms popularised in industrial relations literature by Alan Fox $(1966,1974)$. Thus, some issues were deemed non-negotiable as they were deemed "management prerogatives". The original sympathy and support for unions possibly became

* Department of Management, University of Otago cooler, but remained highly significant. This reasonably stable system started to crumble in 1984 when the Labour Government introduced the first of a number of major changes. Their first change was to do away with compulsory arbitration of "interest disputes" (disputes over the establishment of agreements). Although over the years arbitration had only been used infrequently, it was always available as a last resort. The fact it was available, and would be used if necessary, encouraged parties to settle. In 1984, interest arbitration remained, but only on a voluntary basis. The rest of the changes were introduced (along with a new title) in the Labour Relations Act 1987 (LR Act).

The LR Act retained certain long-standing features, some of the more notable including

1.1 statutory support for unions, including monopoly bargaining rights;

1.2 the possibility of compulsory union membership ("union shop") either if accepted by employer and union, or if voted in by workers;

1.3 the opportunity to negotiate "awards" on district or national level thereby providing minimum standards of wages and conditions to workers on a broad scale;

1.4 "blanket clauses" which resulted in coverage of the award being extended to all employers in the industry or occupation and relevant district(s) - unless they negotiated a separate registered agreement;

1.5 the opportunity to negotiate "agreements" at enterprise level. These could be multiunion composite deals, or productivity or gain-sharing agreements;

1.6 the provision of a service and set procedures to settle rights disputes (over the interpretation or application of contracts and agreements) and personal grievances.

In addition, as stated earlier, the LR Act continued:

1.7 to make available interest arbitration on a voluntary basis.

A major change reflected in this Act was the underlying ideology. Using Alan Fox's terminology, the ideology of the Act was definitely pluralist. It made clear its commitment to collective bargaining, and consequently introduced significant reforms. These included:

2.1 for the first time strikes and lockouts were made explicitly legal. Conditions had to be met, and the action had to be over "interest-type" disputes;

2.2 all issues were made negotiable, doing away with the previous unitarist concept that certain issues were managerial prerogatives and hence non-negotiable;

2.3 radically increasing the minimum number of members required for a union to register from 15 to 1000 .

At the time, these changes were deemed "significant, even radical" (Geare, 1989: 213), but in comparison to those introduced just four years later, they now seem comparatively minor.

The Employment Contracts Act 1991 (EC Act) was introduced by the National Government shortly after winning the 1990 General Election. In marked contrast to the extensive discussion which preceded the passing of the Labour Relations Bill, "the Employment Contracts Bill was introduced with little prior debate and it was made clear no substantial changes would be made to the policies ..." (Anderson, 1991: 129). The EC Act closely mirrored the views of the two major employer lobby groups - the New Zealand Business Roundtable and 
the New Zealand Employers Federation. Not surprisingly, the Act has been labelled "an employers charter" (Anderson, 1991) and, equally unsurprisingly, the two lobby groups claim the Act is a great success and "is making an outstanding contribution to productivity growth" (NZBRT and NZEF, 1991: i)

The EC Act has been analysed elsewhere (Geare, 1993), and in this paper will only be briefly reviewed. The Act rejects the basic underlying presumption of New Zealand's past industria law, namely that employees are inherently in a weaker position than employers and need assistance from the law to redress the balance. The EC Act presumes an individual employee can negotiate on an equal footing with an employer. One must assume the drafters and supporters of the Act are strongly unitarist and believe all, or certainly the vast majority of employers will always operate in the best interests of everyone. If not, they demonstrate a callous disregard for the weaker members of society.

With reference to the long-standing features of New Zealand's industrial relations system, the EC Act rejected four "foundation stones" by:

- abolishing monopoly bargaining rights (1.1);

- making any sort of "closed shop" or "union shop" agreements illegal (1.2);

- abolishing the "blanket clause" (1.4); and

abolishing the Arbitration Commission and thus providing no interest arbitration even on a voluntary basis (1.7)

The EC Act launched a strong attack on a fifth foundation, the national award system (1.3), by making it difficult (although not illegal) to negotiate awards (although it is illegal to strike to include more than one employer in a contract).

Of the three major changes introduced by the LR Act, the EC Act nullified the move to larger, stronger unions (2.3), first by allowing any number of workers to combine, and second, by abolishing union registration. Hence a social club, a section of a department or a national union are all deemed the same - a collective group.

Thus, of the main features of the LR Act, only four remained after the EC Act: $1.5,1.6,2.1$ and 2.2. Indeed, although the EC Act allows 2.2 to remain - that is, all issues remain negotiable - it is somewhat of a "Clayton's" concession, in that the economic conditions, together with the EC Act, have resulted in a generally weakened union movement which is unlikely to make significant unwanted demands over areas deemed "managerial prerogatives". The EC Act at face level is very simple. All issues are up for negotiation, including whether employment contracts are individual or collective. Strikes and lockouts (broadly defined) are legal if they relate to the negotiation of a collective contract, and if there is no collective contract currently in force.

The passing of the EC Act also put paid to any likelihood of workable "Pay Equity" legislation. Certainly it is possible to operate a legislation such as the Equal Pay Act 1972 which makes overt discrimination on the basis of sex an illegal act. However, even with widespread support, enforcing "Pay Equity" or "comparable pay for work of comparable worth", becomes virtually impossible in an environment where a reasonable proportion of people are employed under individual employment contracts.

\section{The proposed Labour Party reforms}

The New Zealand Labour Party has published an Industrial Relations Policy Paper (Policy Paper, 1992), and this, together with the lead paper by Helen Clark (Clark, 1993) are taken as indicative of the sort of industrial law reforms which may be introduced should Labour win the 1993 General Election. Clark claims that Labour will repeal the EC Act 1991 and replace it with an Employment Relations Act.

As an initial observation, neither the Policy Paper nor Clark clearly articulates what needs to be done and how it will be done. Both papers read more like a wish list for the future (which incidentally does not vary that much from the present) than as a carefully thought out and worked through policy. It is possible that this is deliberate, to signal that a wide range of views are being sought, but it is also suggestive that the strategy is to camouflage the fact that the industrial law reforms, should they eventuate, will not make a significant impact.

In considering the reforms, this paper will comment on the intended objectives of the reforms and, where applicable, the methods suggested to achieve them and the probability that legislative changes will be successful. To conclude, the paper will assess the probable impact of the reforms should they eventuate.

There are five explicitly stated objectives listed (Clark, 1993: 154), to which may be added implicit objectives which receive a good deal of emphasis in both the Policy Paper and by Clark, without being formally acknowledged as objectives. These implicit objectives include support for unions, and ratification of ILO Conventions.

\section{Support for unions}

Although it is strongly implied that unions will be given significant support, the reality is closer to being simply that the undermining of unions, resulting both from economic conditions and the EC Act, will be slowed.

Labour is clearly not intending to promote collective bargaining by the obvious methods of either giving effective legislative support to unions, or by ensuring they will be large, reasonably strong, and effective. While it appears at first sight that unions will regain some of their lost prominence in New Zealand industrial relations, given that collective agreement will "only be negotiated by unions" (NZLP, 1992: 3) - this apparent boost is severely restricted by other decisions. Thus, for example, there will be no return to monopoly bargaining rights, which unions enjoyed till 1991, and union membership will be contestable between unions (Clark, 1993: 156). There will be no opportunity for unions to negotiate compulsory membership (union shop or closed shop) agreements since "there will be no return to unqualified preference" (p.155) and Clark also makes clear that "there will be no return whatsoever to the blanket coverage provisions" (p.156). Further, even though Clark uses German prosperity as an example of how high unionisation contributes to success, there is nothing in the proposed reforms which will create, or even encourage the creation of large, strong unions in New Zealand. Although the role model, Germany, had only 14 unions for 6.5 
million workers before unification, Clark proposes to allow any 20 workers to register as a union (p.156). This could well be considered in contradiction to the Policy Paper which claimed a need for "effective industry or sector unions" (NZLP, 1992: 2).

\section{Ratification of ILO conventions}

Ratification is clearly very important to the Labour Party. Discussion about ratification of IL conventions comprises s 2 of the Policy Paper, and Clark claims "a desire to ratify core IIO conventions underlies the entire policy" (Clark, 1993: 155). This seems a peculiar emphasis. The concern should be on the industrial relations system and on how the legislation helps the system to be effective. There should be genuine belief that the system and the legislation are as optimal as possible. If that also allows ratification of ILO conventions, then that is a bonus. Making the ratification per se a major objective is a misplaced concern. Apart from the delegates who actually go to the ILO, almost no one else is affected by (or interested in) the fact as to whether certain politically created conventions are ratified or not. There is, however, widespread interest in the system the legislation creates.

The explicit objectives outlined by Clark (p.154) are:

Growth on an internationally competitive basis;

To promote collective bargaining;

Guaranteed protection from discrimination and unfair treatment ... (and) a fair minimum set of working conditions;

To provide an integrated framework for negotiating wages ... equal employment opportunities (EEO) and workplace reform;

To eliminate destructive wages competition.

\section{Growth on an internationally competitive basis}

This is a laudable objective - but somewhat predictable. (What political party is going to state that it has an objective of depression, stagnation and high unemployment?). The National Government considers the EC Act is designed to increase competitiveness, as does the Employers Federation which states the Act has contributed to "increased real incomes and a significant improvement in New Zealand's competitive position" (NZEF, 1993: 1). Clark implies that with the attainment of the other objectives, growth will come about. No causal link is established, and if there is growth it may or may not be related to the industrial law reform.

\section{To promote collective bargaining}

This objective will have the sympathy of industrial relations pluralists who believe individual workers are generally in a substantially weaker bargaining position than their employer and so that, for most workers, individual bargaining is inherently unfair.

If there is a case at all to argue that there is any substance to Labour's proposed amendments, it relates to this objective. However, that is not to say that even here there will be major upheavals. It is clear there will be no return to the situation under the Labour Relations Act, which did encourage collective bargaining.

Collective bargaining received a severe setback under the EC Act when, for the first time in New Zealand industrial relations, individual bargaining was given legislative recognition as a reasonable alternative. Labour does not intend to significantly change this, and Clark states that "(n)aturally the law will continue to provide for the negotiation of individual contracts by and for those who so choose" (Clark, 1993: 159).

While overseas, particularly American, theorists have claimed that the availability of interest arbitration has a "narcotic" (Wheeler, 1975) or "chilling" (Feuille, 1975) effect on collective bargaining, the experience in this country does not support the allegations. Compulsory arbitration as a last resort encouraged parties to settle during collective bargaining since they could not strike, lockout, or just "hold out" indefinitely. Compulsory arbitration was actually used very infrequently over the years it was available, although the decision that it was assumed would have been made by the arbitral body undoubtedly influenced the negotiated settlement. However, although Clark has expressed considerable admiration for the Canadian system - which does provide voluntary interest arbitration in Federal and most provincial legislation (Kumar, et al., 1987) - there is no overt suggestion Labour will reintroduce voluntary interest arbitration, and it is explicit that there will be "no provision for a return to compulsory arbitration" (Clark, 1993: 159).

One must wonder then, how Labour does in fact intend to "promote" collective bargaining.

Apparently this is to be achieved by legislating that parties must bargain "in good faith" (p.158). The Policy Paper alleges that there will be mechanisms provided in the legislation which ensure a speedy resolution to any claims that good faith bargaining is not occurring" (NZLP, 1992: 4). This will apparently be the duty of a newly established body, the "Employment Relations Commission". Although Clark believes that Canada has avoided some of the problems the United States has had with good faith bargaining, and that somehow Labour's system will be an improvement over the Canadian system, the likelihood that there will be speedy resolution to the legal arguments created over this proposal is highly remote.

The duties for good faith bargaining are spelled out by Clark (1993: 158). The first two - to meet and consider proposals, and to respect the choice of representatives - are not too onerous given that "there will not be a legal duty to reach a settlement" (p.159). However, the third duty is likely to prove contentious. This is the duty to provide "relevant information". Again, the hope is expressed that the Employment Relations Commission will be able to quickly decide what is relevant. This writer can foresee three scenarios. One is that employers learn to avoid arguments which can render information "relevant". That is, they do not argue "we cannot afford to grant the increase" - which may render them liable to divulge their financial position, but rather argue "we do not choose to grant the increase" -which would not necessitate divulging information to support the claim. The second scenario is that there will be, in certain cases, hotly contended legal battles to defend the right to keep financial 
information confidential. The third scenario is that certain information is divulged, but with no guarantees that it is complete and accurate.

Further reforms relating to collective bargaining processes are suggested with respect to strikes and lockouts. However, there has already been a significant watering down of the reform from the Policy Paper to Clark, so it is probable the final amendments may be even more superficial. The Policy Paper states emphatically that "a mechanism will be introduced to ensure legally striking or locked out workers cannot simply be replaced by others on lesser conditions of employment" (p.5). Clark, on the other hand, merely states that "employers will not be able to lockout workers who are not part of the collective bargaining" (Clark, 1993: 160) - which is, of course, current law - and goes on "nor will they be able to require them to perform the work of those on strike or who are locked out. It will be unlawful for the employer to insist that another worker perform the work of one who is lawfully on strike or locked out" (my emphases). Thus, the latest position allows employers to get other workers who are willing to do the work, and to take the place of those locked out - a significant step down from the position held by the Policy Paper.

One stated amendment which could appear to be of some significance is that strikes or lockouts in pursuit of a multi-employer agreement would be legal (p.158). Such strikes were made illegal under the EC Act purely as part of the strategy to destroy the national award system. There was no logical justification for that position, and it did not fit into the professed ideology of the EC Act. The second part of the strategy to destroy the award system was to abolish "blanket coverage". As stated earlier, the blanket clauses will not be reintroduced. Thus, one of the main advantages of having a multi-employer agreement will still be missing. Making strikes legal certainly removes an illogicality - but it is not of much moment.

Clark also states that partial lockouts "will not be lawful" (p.160). Partial lockouts came into prominence and are epitomised by the case Paul v New Zealand Society for the Intellectually Handicapped WEC 1/92 [1992] 4 NZELC 95528. In this case, the IHC committed a "partial lockout" by reducing its employees' remuneration. It was deemed lawful since the action was a partial breach of contract, with the purpose being to get the employees to agree to a new collective employment contract. By law the action was a lockout, and a lawful one. The partial lockout is deemed the equivalent of a "go-slow" by workers, which is in effect a partial strike.

To illustrate, in a normal employment situation there is an exchange, with an employer providing wages and benefits and workers providing work (and/or time and skills). In a goslow, workers reduce their side of the bargain (the work) while receiving in full the employer's side (wages and benefits). In a partial lockout there is a reverse. The employer reduces its side of the bargain (wages and benefits) while hoping to receive in full the workers' side (work). In an amazing argument, Clark claims that "the employer will have to do as workers do, and reduce the work that is offered, rather than the wages paid for that work" (p.160). To be consistent, Clark should then demand that in a go-slow workers demand their wages be reduced. Partial lockouts can cause hurt and inconvenience, as can partial strikes. That is the point of the exercise. Once you permit strikes and lockouts (partial or total), you have to accept that there will be unpleasantries. This proposed reform seems like a knee jerk reaction to a notorious case, and has not been well thought through.
It would not be surprising if, in the finish, it does not become legislation.

Guaranteed protection from discrimination and unfair treatment ... (and) a fair minimum set of working conditions

The first part of this double-barrelled objective is apparently necessary because it is claimed that the tests for workers to show discrimination are "set very high" and it is alleged that in "the decided cases" workers are required to prove every element of the allegation (Clark, 1993: 155).

There is no supporting evidence for this bold allegation. Published cases involving alleged discrimination over union activities are very few and far between. The cases published in the NZELC series of cases reveal 1990: one case, 1991: no cases, 1992: no cases of discrimination over union activities. In the only published case mentioned (Post Office Union $v$ Telecom [1990] 3 NZELC, 97511) the Court ruled, "the onus of proof rests with the applicant union and the burden of proof is in the balance of probabilities $(97,530)$ " which is a very different matter from the union having "to prove" each allegation. "Proving" allegations, suggests proof beyond reasonable doubt which is much more rigorous than the stated balance of probabilities.

This issue is really just a red herring.

The second "barrel" of the objective alleges a minimum set of working conditions will be established, but nothing is made explicit beyond a commitment "to undertake a review of minimum wage levels" and ensure there are minimum wages "for those aged under twenty" (Clark, 1993: 161). Thus, very little is guaranteed. It is quite probable that the little that is promised will be pre-empted by National before the election.

To provide an integrated framework for negotiating wages ... equal employment opportunities (EEO) and workplace reform

It is significant that in the Policy Paper EEO received a reasonable degree of emphasis. It was mentioned in the five objectives as per Clark's paper, but in addition also merited a section on its own. On the front page of the Policy Paper, it was stated that, "basic provisions for pay equity and equal employment opportunities will be an integral part of industrial relations policy (NZLP, 1992: 1). Clark's paper gives EEO and pay equity much less emphasis. It remains as an objective, but receives little other attention. Of course, once an industrial relations system permits individual bargaining and hence individual contracts, the evidence required to demonstrate pay inequity will be extremely hard to find. The mechanism for introducing pay equity implies some central arbitral body with the power to set national or regional awards. This has been rejected.

The issue of "workplace reform" still receives a good deal of attention in Clark's paper. However, for some time already, workplace reform has been the flavour of the month and it would appear that New Zealand is experiencing the cyclical resurrection of interest in "worker 
involvement in decision-making" (Clark, 1993: 153) that Ramsey referred to a quarter of a century ago (Ramsey, 1977). In a more recent article he states his current research in the United Kingdom confirms how little strategic thinking goes into this area; rather organisations "try things out due to their general disposition or because ideas are fashionable at a particular juncture" (Ramsey, 1993: 77).

If workplace reform is defined as "mutually accepted improvements in the workplace", then by definition it must be a good thing. If, on the other hand, "workplace reform" mean "worker involvement in decision making", as suggested by Clark, then past history suggests may be beneficial, to some parties in some circumstances. It certainly has not been accepted as generally beneficial.

Neither Clark nor the Policy Paper clearly indicates how workplace reform will be achieved, other than as an apparently inevitable spin-off of the Employment Relations Act.

\section{To eliminate destructive wages competition}

One can but assume that the soon to be created Employment Relations Commission will somehow achieve this objective. Although this is stated as an objective both in the Policy Paper and by Clark, there is no comment on how it will be achieved, or even how it is hoped it will be achieved.

\section{Legislative detail}

Given that Helen Clark's paper is a backgrounder to Labour Party policy and is not a draft Bill, there can be little comment on actual legislative detail. There are, however, a number of statements made in Clark's paper which merit comment. In addition, it is to be hoped the standard of draftsmanship is an improvement on current legislation.

Clark states that "collective bargaining will be initiated by the union where there is no existing applicable collective agreement" (Clark, 1993: 157). There is no logical reason to preclude employers from initiating collective bargaining in the absence of a collective agreement if they choose. One can but presume this is a back door attempt to prevent lockouts. If Labour is opposed to strikes and lockouts, then the Party should bite the bullet and accept the consequence - compulsory arbitration.

If a collective agreement is in existence then Labour would permit either the employer or the union(s) to initiate collective bargaining. Unions may initiate proceedings sixty days prio to expiry, employers not until forty days prior to expiry. This is presumably because Labour wants the union to be the initiator and presumably believes this is of some significance. This distinction seems unnecessary and undesirable.

Clark states that collective agreements will have as one of four basic requirements "procedures for dealing with new matters" (p.157). Although the issue of "new matters" was controversial when introduced by the LR Act 1987, it did not have the impact possibly anticipated. It will have even less impact if it is reintroduced, given that there has been a substantial move away from awards to enterprise agreements. Enterprise agreements can be worded so that any matter would not legally be defined as a "new matter". Indeed, simply giving notice of future actions prior to negotiating the agreement makes the matter not "new". In one of the few published cases involving new matters under the LR Act, Airline Stewards and Hostesses v Ansett New Zealand [1991] 4 NZELC 95201, Colgan J ruled that because the union had known the management action was a possibility before they negotiated their agreement, but failed to consider the matter in negotiations, this meant that when management introduced the matter later on it was not "new".

\section{Draftsmanship}

As has been outlined elsewhere (Geare, 1993), the Employment Contracts Act 1991 contains a number of inconsistencies and ambiguities. Thus, s81(5) states the same Tribunal member "shall not perform both mediation services and adjudication services", while s88(2) allows for the same member to provide mediation and also to "make a decision" - or, as most would

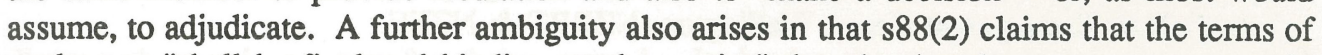
settlement "shall be final and binding on the parties", but the Act then goes on to state in s95(1) that any party to any proceedings before the Tribunal "may appeal". It is to be hoped that, if a new Act is to be drafted, there is some clear thinking as to its objective and sections are drafted unambiguously.

\section{Conclusion}

It may well be an election strategy of the Labour Party to promise very little by way of specifics and thus avoid the accusations levelled at the 1984 and 1987 Labour Governments, and the 1990 National Government, that they all failed to deliver their election promises. Certainly there are few specific undertakings other than the now totally predictable one that the title of the principal legislation will be changed. Unless the eventual amendments are considerably more far-reaching than Clark's paper would suggest, there is absolutely no need for a name-change. It is possible that legislation with respect to "good faith" bargaining may create a bit of a stir in some circles, some more work for the legal profession, and possibly some change to bargaining behaviour. However, in all, the proposed Labour reforms as indicated by Clark's paper tend to be superficial rather than substantial, and are cosmetic rather than creative.

\section{References}

Anderson, G. (1991), "The Employment Contracts Act 1991: an employers' charter?" New Zealand Journal of Industrial Relations, 16(2): 127-142.

Clark, H. (1993), "Employment Relations - the New Direction under Labour", New Zealand Journal of Industrial Relations, 18(2): 153-162. 
Feuille, P. (1975), "Final Offer Arbitration and the Chilling Effect", Industrial Relations, 14(3): $302-310$

Fox, A. (1966), Industrial Sociology and Industrial Relations, London, HMSO.

Fox, A. (1974), Beyond Contract: Work, Power and Trust Relations, London, Faber.

Geare, A.J. (1989), "New Directions in New Zealand Labour Legislation: The Labour Relations Act 1987", International Labour Review, 128(2): 213-228.

Geare, A.J. (1993), A Review of the New Zealand Employment Contracts Act 1991, Dunedin, FIRRE.

Kumar, P., Coates, M.L. and Arrowsmith D. (1987), The Current Industrial Relations Scene in Canada, Kingston, Queens University.

New Zealand Business Roundtable and New Zealand Employers Federation (1992), A Study of the Labour/Employment Court, Wellington, NZBRT \& NZEF.

New Zealand Employers Federation (1993), The Employer, Wellington, NZEF.

New Zealand Labour Party (1992), Industrial Relations Policy Paper, Wellington, NZLP.

New Zealand Official Year Book 1973 (1973), Wellington, Government Printer.

Ramsey, H. (1977), "Cycles of Control: worker participation in sociological and historical perspective", Sociology, 11(3): 481-506.

Ramsey, H. (1993), "Recycled Waste: response to Ackers et al.", Industrial Relation Journal, 24(1): 76-80.

Wheeler, H.N. (1975), "Compulsory Arbitration: A 'Narcotic Effect'?", Industrial Relations, 14(1): $117-120$

Woods, N.S. (1974), "The Industrial Relations Act 1973", Occasional Papers 11, Wellington, Victoria University of Wellington.

\section{Forward to the Past: the Labour Opposition's Industrial Relations Policy}

\section{New Zealand Employers Federation}

To read the Rt. Hon. Helen Clark's account of Labour's current industrial relations policy is to be overcome by an extraordinary sense of deja vu. Some of the detail may be different, but the general impression is the same. Like returning to scenes of childhood, we have all been here before.

The opening paragraph reveals a contradiction. If New Zealand has been trailing the more dynamic economies for years, why should a move back to policies very like those which have failed in the past produce a better result?

Paragraph two is on equally shaky ground. It decries the attachment of New Zealand employers to top down decision-making, but overlooks the fact that a union presence in the workplace has frequently hampered, rather than encouraged, the communication process. Employee involvement in decision-making is a very different thing from the kind of union involvement so characteristic of New Zealand industrial relations in the recent past.

And yet, as the third paragraph makes plain, it is union, not employee involvement which this industrial relations policy is contemplating, and just at a time when the Employment Contracts Act has seen more employers than ever before talking directly to their employees, to the benefit of all parties. It has not been an overnight change but it is happening and the impetus is likely to increase. Employers operating in a competitive economy will not be slow to realise that harmonious industrial relations ensure a competitive edge. Competition is a far more effective imperative than compulsion.

By contrast, what Helen Clark and Labour's policy advocate is a return to the automatic involvement of organised labour in an employer's affairs through the provision of the kind of base union support which makes possible the pursuit of union, rather than employee, interests. If unionism in New Zealand was formerly defensive and inward-looking, as the Policy Paper states, that was precisely because it had no reason to be otherwise. If we have learned anything we should now know that providing unions with statutory protections removes their need for a broader vision. Only in the absence of protection, with proper membership accountability required (as it is under the Employment Contracts Act), is the need for a genuinely expanded view likely to be recognised.

Helen Clark's paper quotes the world's more successful economies with particular reference to the German situation. But consider this quote from a recent (May 31 1993) issue of the American periodical, Business Week: 